\title{
KESULITAN PEMBELAJARAN MATEMATIKA SEKOLAH INKLUSI UNTUK ANAK ABK
}

\author{
Chatarina Febriyanti ${ }^{1}$, Mohamad Lutfi Nugraha ${ }^{2}$ \\ Program Studi Informatika, Universitas Indraprasta PGRI ${ }^{1,2}$ \\ Email: chatarina022@gmail.com ${ }^{1}$
}

\begin{abstract}
Abstrak
Penelitian ini bertujuan untuk mengetahui bagaimana kesulitan belajar matematika anak berkebutuhan khusus di sekolah inklusi. Lokasi penelitian ini ada di Kota Depok Jawa Barat, mengambil lokasi penelitian dengan menggunakan teknik samping terpilih yaitu SDIT Akhdor Insan Mulia.. Dengan sampel penelitian adalah anak yang berkebutuhan khusus kategori sedang dan rendah, serta anak berkebutuhan khusus dengan kategori slow learner. Metode penelitian ini adalah survey eksploratif dengan pendekatan kualitatif. Dari hasil penelitian ini didapatkan bahwa proses pembelajara nmatematika untuk anak berkebutuhan khusus memerlukan penanganan khusus serta kurikulum yang disesuaikan dengan kemampuan awal siswa sehingga setiap siswa berkebutuhan khusus akan ada perbedaan dalam kurikulum matematika dengan anak-anak yang reguler.
\end{abstract}

Kata kunci : Inklusi, Matematika, Anak Berkebutuhan Khusus

\begin{abstract}
The research is aimed at knowing the difficulty with mathematics learning facing by students with special needs in an inclusive school. The research location chosen using a selected sampling technique is SDIT Akhdor Insan Mulia in Depok, West Java. The sample of the research is students with special needs with medium category and low category and students with special needs with slow learner category. The method of the research is an explorative survey with a qualitative approach. From the research result, it can be concluded that mathematics learning process for students with special needs requires a special treatment and a curriculum adjusted to the initial student's ability so that students with special needs have a different mathematics curriculum than that of regular students.
\end{abstract}

Keywords : Inclusion, Mathematics, Students with Special Needs

\section{PENDAHULUAN}

Dalam Pancasila yang ke dua yang berbunyi kemanusiaan yang adil dan beradab. Dan sila ke lima yang berbunyi keadilan sosial bagi seluruh rakyat Indonesia. Maka dari itu kiranya perlu adanya keadilan dalam bidang pendidikan dimana pendidikan menjadi hak setiap warga negara yang dijamin oleh pemerintah. Namun pada kenyataanya masih banyak dari masyarakat Indonesia yang belum mendapatkan pendidikan yang layak padahal dalam UUD 45 Bab X Pasal 27 yang menyatakan bahwa "Tiap-tiap warga negara berhak atas pekerjaan dan penghidupan yang layak bagi kemanusiaan." Dari pasal tersebut terlihat pendidikan merupakan salah satu cara untuk mendapatkan pekerjaan dan penghidupan yang layak, namun pada kenyataanya pendidikan belum dapat dirasakan oleh sebagian dari rakyat Indonesia karena beberapa faktor.

Pendidikan merupakan sarana untuk menuju ke penghidupan yang layak maka perlu dikembangkan pendidikan bagi semua kalangan. Yang menjadi perhatian adalah ketika ada perbedaan perlakuan pemerintah terhadap anak-anak yang memiliki kebutuhan khusus dalam pendidikan belum terakomodir oleh 
pemerintah sehingga banyak anak-anak yang memiliki kebutuhan khusus tidak dapat mengenyam pendidikan yang layak sebagaimana yang diterima oleh anak-anak reguler pada umumnya. Hal ini menjadi perhatian khusus pemerintah dalam membina dan mengembangkan solusi pendidikan berbasis inklusi kebeberapa sekolah umum yang menjadi wadah bagi anak-anak berkebutuhan khusus untuk dapat mengenyam dan merasakan pendidikan seperti layaknya anak-anak reguler.

Menurut UU No 20 Tahun 2013 Bab 1 Pasal 1 Nomor 18 dimana disebutkan "Wajib belajar adalah program pendidikan minimal yang harus diikuti oleh warga negara Indonesia atas tanggung jawab pemerintah dan pemerintah daerah". Hal ini berarti setiap warga negara berhak mendapatkan pendidikan minimal atau yang biasa disebut wajib belajar yang dicanangkan pemerintah saat ini adalah wajib belajar 9 tahun dimana warga negara berhak untuk mendapatkan minimal pendidikan sampai dengan tingkatan sekolah menangah pertama (SMP). Wajib belajar yang dicanangkan pemerintah belum dapat mengakomodir kebutuhan warga negara akan pendidikan minimal karena masih banyaknya anak-anak di Indonesia yang masih belum dapat melanjutkan pendidikan ke jenjang berikutnya. Hal ini pun berdampak pada kenyataan dimana anak-anak berkebutuhan khusus belum dapat mengenyam pendidikan yang layak pada tingkatan wajib belajar yang dicanangkan pemerintah.

Anak berkebutuhan khusus memiliki hak yang sama seperti anak-anak reguler pada umumnya dalam mengenyam pendidikan. Oleh karena itu sudah banyak sekolah inklusi yang dibina oleh pemerintah sebagai sarana pemerataan pendidikan bagi anak-anak berkebutuhan khusus. Namun dalam perjalananya sekolah Inklusi menghadapi beberapa hambatan atau kendala seperti belum siapnya penerimaan masyarakat jika ada anak berkebutuhan khusus yang sekolah sama seperti anakanak reguler pada umumnya. Hal ini menyebabkan akan sulit bagi orang tua anak berkebutuhan khusus siap menyekolahkan anak mereka pada sekolah reguler karena belum adanya kesadaran masyarakat atau cara pikir masyarakat umum bahwa anak berkebutuhan khusus tidak dapat dijadikan satu sama seperti anak-anak reguler lainya.

Belum lagi pada saat proses pembelajaran dikelas dimana akan terjadi paradigama peserta didik reguler lainnya jika untuk anak berkebutuhan khusus saja dapat lulus atau naik kelas maka hal tersebut sangat mudah bagi peserta didik yang reguler untuk membenarkan diri bermain-main dalam proses belajar. Kendala kurikulum dan sistem penilaian anak berkebutuhan khusus yang mungkin akan membuat bingung guru pengajar dalam memberikan penilaian dan evaluasi apa bila pemerintah tidak memberikan acuan bagi pendidik tentang kurikulum, proses pembelajaran dan proses penilaian anak berkebutuhan khusus sehingga dapat menimbulkan penilaian yang subjektif. Maka dari itu perlu adanya aturan-aturan tentang pendidikan inklusi secara menyeluruh agar pendidikan inklusi yang dikembangkan pemerintah dapat lebih baik lagi. Pada penelitian ini kami menelaah proses kegiatan pembelajaran matematika pada anak berkebutuhan khusus dengan kategori autis sedang dan slow learner.

Matematika adalah ilmu tentang bilanganbilangan, hubungan antar bilangan dan antar masalah mengenai bilangan (KBBI, 1997: 637). Matematika adalah cabang ilmu pengetahuan eksak dan terorganisir secara sistematik. Materi yang diajarkan disesuaikan dengan perkembangan intelektual siswa, sehingga semakin tinggi 
jenjang sekolahnya semakin komplek materi yang dipelajari, karakteristik matematika yakni: (1) objek matematika adalah abstrak, (2) simbol-simbol kosong dari arti, (3) kesepakatan dan pemikiran deduktif aksiomatik, (4) taat asas atau tidak kontradiksi, (5) kesestaan sebagai pembatas pembahasan [1].

Menurut Hildegun Olsen dalam Tarmansyah pengertian pendidikan inklusi adalah sekolah harus mengakomodasi semua anak tanpa memandang kondisi fisik, intelektual, sosial emosional, linguistik atau kondisi lainnya [2]. Ini harus mencakup anak-anak penyandang cacat, berbakat. Anak-anak jalanan dan pekerja anak berasal dari populasi terpencil atau berpindah-pindah. Anak yang berasal dari populasi etnis minoritas, linguistik, atau budaya dan anak-anak dari area atau kelompok yang kurang beruntung atau termajinalisasi. Pemerintah melalui Permendiknas Nomor 70 Tahun 2009 tentang Pendidikan Inklusif bagi peserta didik yang memiliki kelainan dan memiliki potensi kecerdasan dan atau bakat istimewa untuk mengikuti pendidikan atau pembelajaran dalam lingkungan pendidikan secara bersama-sama dengan peserta didik pada umumnya. Dalam pelaksanaannya, pendidikan inklusi bertujuan untuk memberikan kesempatan yang seluas-luasnya kepada anak berkebutuhan khusus dan mewujudkan penyelenggaraan pendidikan yang menghargai keanekaragaman, tidak diskriminatif kepada semua peserta didik yang memiliki kelainan fisik, emosional, mental, dan sosial, atau memiliki potensi kecerdasan dan bakat istimewa untuk memperoleh pendidikan yang bermutu sesuai dengan kebutuhan dan kemampuannya. Inti dalam pendidikan inklusi yaitu system pemberian layanan pendidikan dalam keberagaman, dan falsafahnya yaitu menghargai perbedaan semua anak.
Anak dengan kebutuhan khusus (special needs children) dapat diartikan secara simpel sebagai anak yang lambat (slow) atau mengalami gangguan (retarded) yang tidak akan pernah berhasil di sekolah sebagaimana anak-anak pada umumnya. Menurut Heward dalam Shinta anak berkebutuhan khusus adalah anak dengan karakteristik khusus yang berbeda dengan anak pada umumnya tanpa selalu menunjukan pada ketidakmampuan mental, emosi atau fisik. Anak berkebutuhan khusus (ABK) adalah definisi yang sangat luas, mencakup anakanak yang memiliki cacat fisik, atau kemampuan IQ rendah, serta anak dengan permasalahan sangat kompleks, sehingga fungsi-fungsi kognitifnya mengalami gangguan [3].

Tujuan dari penelitian ini adalah untuk memberikan kontribusi bagi guru matematika tingkat sekolah dasar untuk dapat mengetahui karakteristik siswanya serta mengetahui faktor-fakator yang membuat pembelajaran menjadi sulit bagi siswa dan mencari solusi untuk mengatasi kesulitan belajar matematika pada anak berkebutuhan khusus. Selanjutnya adalah untuk memberikan faktor-faktor pendukung dalam mencari solusi untuk mengatasi kesulitan belajar dan mengetahui karakteristik setiap anak berkebutuhan khusus yaitu dalam penelitian ini melakukan observasi langsung dan tak langsung. Dimana setiap anak berkebutuhan khusus dilihat secara langsung dalam proses pembelajaran di kelas.

Untuk anak berkebutuhan khusus supaya lebih baik lagi dalam belajar matematika sehingga diharapkan dapat membawa kearah yang lebih baik lagi tenatang prestasi dan hasil belajar yang dimilki karena mereka mendapatkan perlakuan khusus yang berbeda-beda antara siswa dengan karakteristik yang berbeda. 
Selanjutnya mereka dapat mengoptimalkan karakteristiknya mereka dalam hal ini adalah guru pendamping yang selalu mengobservasi dan mendampingi siswa dalam mengatasi kesulitan belajar matematika.

\section{METODE}

Penelitian ini dilaksanakan di SDIT Akhdor Insan Mulia berada di kecamatan Cimanggis, dan berada dalam administrasi Kota Depok. Penelitian ini dilaksanakan mulai April - Juni 2016, dimana yang menjadi sampel pada penelitian ini adalah anak-anak berkebutuhan khusus kelas 5 dengan katagori autis sedang dan ringan dan slow learner pada level keterbatasan masing-masing. Metode yang digunakan dalam penelitiani ini dalah survey ekslporatif tanpa memberikan perlakuan khusus pada sampel penelitian. Instrumen yang digunakan berupa panduan observasi dan wawancara yang dilakukan kepada guru kelas, guru pendamping dan ketua inklusi yang khusus menangani anak-anak berkebutuhan kusus tersebut.

Jenis penelitian ini adalah penelitian kualitatif deskriptif eksploratif . Responden dari penelitian ini adalah guru mata pelajaran matemtika, guru pendamping ABK dan peserta didik Anak Berkebutuhan Khusus (ABK) Sekolah Dasar Inklusi yang berada di wilayah Kota Depok. Jumlah Sekolah Dasar inklusi dan peserta didik yang dijadikan sampel dari penelitian ini diambil dengan teknik pengumpulan data secara bertahap (multistage sampling).

Penentuan subjek penelitian dalam penelitian kualitatif, dapat menggunakan model criterion-based selection yang didasarkan pada asusmsi bahwa subjek tersebut sebagai aktor dalam tema penelitian yang diajukan. Selain itu dalam penentuan informan, dapat menggunakan model snow ball sampling untuk memperluas subjek penelitian. Hal lain yang perlu diketahui bahwa penelitian kualitatif lebih didasari pada kualitas informasi yang terkait dengan tema penelitian yang diajukan.

Pengumpulan data pada penelitian ini adalah dengan berbagai cara yaitu dengan wawancara, observasi, dan dokumen yang diperoleh dari subjek penelitian dan yang terlibat di dalamnya. Setelah rangkaian data terkumpul, selanjutnya dilakukan analisis data dengan prosedur dan teknis pengolahan berikut : (1) Melakukan pemilahan dan penyusunan klasifikasi data; (2) Melakukan penyunting data dan pemberian kode data untuk membangun kinerja analisis data; (3) Melakukan konfirmasi data yang memerlukan verifikasi data dan pendalaman data; dan (4) Melakukan analisis data sesuai dengan konstruksi pembahasan hasil penelitian.

Pengolahan data dilakukan dalam beberapa tahapan. Tahap pertama pengolahan data dimulai dari penelitian pendahuluan hingga tersusunnya usulan penelitian. Tahap kedua, pengolahan data yang lebih mendalam dilakukan dengan cara mengolah hasil kegiatan wawancara dan pengumpulan berbagai informasi lapangan di lokasi penelitian. Tahap ketiga, setelah itu dilakukan pemeriksaan keabsahan data hasil wawancara dengan sejumlah nara sumber yang dijadikan informan penelitian serta membandingkan data tersebut dengan berbagai informasi yang terkait. Pada tahap ini, pengolahan data dianggap optimal apabila data yang diperoleh sudah layak dianggap lengkap dan dapat merepresentasikan masalah yang dijadikan obyek penelitian. Tahap akhir adalah analisis data dalam rangka menjawab pertanyaan-pertanyaan penelitian yang dilakukan dengan pendekatan analisis kualitatif. 


\section{HASIL DAN PEMBAHASAN}

Sekolah Akhdor Insan Mulia berada di alamat : J1. Bungur Raya no 32 memiliki Keunggulan 1) Membangun karakter, motivasi, dan entrepreneur siswa, 2) Kelas kecil (max 15 siswa), 3) Pembelajaran Sistem Sentra dengan metode BCCT (Beyond ang circle times), 4) Kurikulum nasional, 5) Integrated and Active Learning, 6) Mengembangkan aspek spiritual dan multiple intelegent, 7) Tritingual. Kurikulum Akhdor Insan Mulia menggunakan Kurikulum Nasional yang diintegrasikan dengan pendidikan Spiritual dan Akhlakul Khotimah atas dasar Teori Perkembangan Anak, mengacu pada prinsip Bermain Sambil Belajar melalui pengayaan lintas Kurikulum untuk mengoptimalkan IQ, SQ, EQ secara berimbang terhadap lingkungan anak-anak.

Program belajar mengembangkan 5 aspek perkembangan dalam rangka memaksimalkan tahap-tahap perkembangan anak. 1) Perkembangan kecerdasan intelektual, emosional dan spiritual, 2) Perkembangan Bahasa dan karakter serta entrepreneur, 3) Perkembangan fisik/motoric kasar dan halus, 4) Perkembangan social, 5) Perkembangan kognitif. Selain itu program Bahasa kami mengembangkan 6 bidang kemampuan dasar kecerdasan Agama, Bahasa, Daya Pikir, Daya Cipta, keterampilan dan Jasmani) sebagai nama sentral.

Program pendukung adalah 1) Konsultasi kesehatan, 2) Rekreasi dan Field Trip, 3) Renang, Education Visit sesuai tema, 4) Cooking time, Moving Class dan Manasik Haji, 5) Pengembangan kecerdasan emosi dengan penanaman rasa seni, 6) Pengembangan optimal tumbuh kembang anak dengan suasana bermain sambil belajar yang kondusif, 7) Perayaan hari besar Islam, 8) Parenting day, 9). Program bazzar murah/bakti social
Program pendidik untuk meningkatkan mutu para guru, maka Akhdor Insan Mulia melakukan beberapa cara, yaitu 1) Lesson study, dengan melibatkan Observer (penilai) dari lembaga formil (Diknas). Orang tua siswa, Yayasan untuk menilai pada saat guru mengajar di kelas, 2) Melakukan seleksi guru teladan, berprestasi dan kreatif yang dilakukan 6 bulan sekali, 3) Para pendidik mendapatkan pelatihan Bahasa inggris, arab dan tahsin setiap 1 pekan sekali, 4) Pendidik diharuskan mengikuti kegiatan Forsil Guru TK dan SD sejabotabek. Pendidik diberikan kesempatan untuk mengikuti workshop atau seminar-seminra pada waktu tertentu.

Dari hasil pengamatan dan penelitian yang kami lakukan selama kurang lebih tiga bulan maka kami dapat melihat bagaimana dan seperti apa proses pembelajaran matematika yang di lakukan pada sekolah inklusi.Sebelum lebih jauh lagi kepada pembahasan selanjutnya, kami akan membahas hasil observasi dan wawancara kami di sekolah-sekolah inklusi.

Pada siswa reguler mereka mempunyai bahan ajar yang sesuai dengan tuntutan kurikulum yang dipakai di SD Lentera Insan. Namun untuk anak spesial yang mempunyai kategori sedang maka bisa dimasukan kedalam kurikulum yang diberikan namun ada tambahan kurikulum pengembangan diri dimana pada tahapan dan proses pembelajaran matematika yang dilakukan di kelas anak reguler diberikan materi ajar seperti biasa oleh guru kelasnya begitupun untuk anak spesial. Namun ada tambahan pada anak spesial yaitu shadow theacher yang pada sekolah lentera insan di sebut dengan gisma (guru istimewa) melatar belakangi guru-guru yang mendampingi anak spesial tersebut selama di dalam kelas dan mengawasinya diluar kelas. Pada masing-masing kelas paling banyak terdapat 4 siswa spesial itupun 
dibatasi pada level sedang dan rendah saja keterbatasanya. Namun untuk yang berat maka ada kelas khusus atau bisa disebut kelas persiapan sebelum anak spesial masuk kedalam kelas reguler.

Sebagai contoh kurikulum yang diterapkan pada mata pelajaran matematika materi bangun ruang. Jika pada anak reguler dituntut untuk menghitung luas, namun pada siswa spesial cukup sampai pada siswa mengenal dan membedakan bangun datar segitiga, segiempat dan nama-nama bangun tersebut sampai mereka hafal dan memahaminya. Dengan kata lain kurikulum yang dibuat untuk siswa istimewa telah disesuaikan dengan kemampuan mereka berdasarkan assesment yang dilakukan oleh pihak sekolah dan psikolog.

Pembelajaran matematika yang diberikan pada anak spesial tidak begitu terlalu mendalam namun hanya pada kemampuankemampuan pemahaman saja. Seperti mampu berhitung penjumlahan, pengurangan dan pembagian dibatasi hal ini dikarenakan pada siswa spesial pembelajaran yang dilakukan harus berulang-ulang.

Siswa spesial tidak juga diajarkan kemandirian dalam kehidupannya misal jika mau pipis harus di toilet dan sebagainya. Suasana pembelajaran yang berlangsung di kelas dalam pengamatan mata kami semua berjalan normal seperti pembelajaran siswa umum pada biasanya, siswa disana juga aktif-aktif dalam proses pembelajaran yang terjadi selain itu diluar kelas diberikan ruangan khusus untuk orang tua mengamati anaknya dimana ada kaca khusus yang bisa terlihat kedalam namun yang dari dalam tidak bisa melihat keluar. Sehingga penelitipun dalam menjalankan penelitiannya tidak melakukan ganguan terhadap pembelajaran di kelas berjalan normal sebagimana biasa. Begitupun siswa spesial didampingi oleh gisma belajar sebagaimana biasa. Namun ada pada saat kami melakukan penelitian siswa ada yang sedang tantrum atau bahasa lainya adalah mengamuk. Ketika itu gisma membawanya keruangan khusus untuk ditangani lebih lanjut

Penilaian yang dilakukanpun berdasarkan beberapa aspek kognitif, afektif dan psikomotorik selain ini ada juga aspek perkembangan individu. Dalam raport tersebut terdapat narasi yang diberikan oleh guru tentang perkembangan siswa apa saja yang sudah dicapai dan belum dicapai oleh siswa spesial tersebut. Selama proses belajar mengajar, sering kali guru harus mendampingi secara khusus anak $\mathrm{ABK}$ tersebut. Misalnya dengan cara membantu membuat garis atau membuat angka untuk ditulis berulang-ulang. Pada dasarnya anak-anak ABK sering kali lupa pelajaran yang diajarkan. Bahkan untuk belajar mengenal bentuk-bentuk bangun datar, untuk sampai faham bias memakan waktu 1 tahun pembelajaran. Untuk siswa ABK di Akhdor Insan Mulia dengan diagnose autis sedang, lebih cenderung pendiam dan tidak temperamen. Menurut guru yang menangani memang sudah mengalami banyak peningkatan dibanding dulu pada waktu masih awal belajar di sekolah. Pada pertama masuk sering kali tantrum dan mogok belajar. Pengajar sering kali harus membujuk agar mau masuk ke kelas. Pada saat ini responden sudah rajin belajar, walaupun sering kali masih bengong dan menolak jika ada orang asing masuk kedalam kelas. Sejauh ini responden bias mengikuti semua materi yang diajarkan.

Berdasarkan kenyataan dilapangan yang kita lihat bahwa kesiapan sekolah untuk menerima anak berkebutuhan khusus masih sangat minim persiapan mulai dari tenaga pendidik, kurikulum yang harus menyesuaikan dengan kemampuan anak, serta sarana dan prasarana pendukung pembelajaran. Pada kenyataanya sekolah 
berbasis pemerintah atau negeri banyak belum siap untuk melaksanakan sekolah inklusi, masih agak memungkinkan untuk diterapkan di sekolah-sekolah swasta. Pembelajaran matematika yang disajikanpun akan berbeda antara sekolah satu dengan yang lainnya. Oleh karena itu analisis kesulitan pembelajaran matematika pada anak berkebutuhan khusus di sekolah inklusi mempunyai ciri khas yang berbeda antara satu sekolah dengan sekolah lainya.

Tabel 1. Situasi Sekolah Inklusi

\begin{tabular}{|c|c|c|c|}
\hline No & $\begin{array}{c}\text { Jumlah } \\
\text { anak ABK }\end{array}$ & Sarana prasarana & Kurikulum \\
\hline 1 & $\begin{array}{c}\text { Autis autis } \\
\text { ringan } 1 \text { anak }\end{array}$ & $\begin{array}{l}\text { Anak Berkebutuhan khusus di sekolah Akhdor } \\
\text { Insan Mulia belajar bersama dalam } 1 \text { kelas. } \\
\text { Pendampingan diberikan jika ABK memang } \\
\text { butuh pemahaman lebih pada materi yang } \\
\text { diberikan sehingga pengawasan tidak dilakukan } \\
\text { secara terus menerus }\end{array}$ & \begin{tabular}{lrr}
\multicolumn{2}{l}{ Tidak terdapat } & kurikulum \\
khusus yang & berbeda \\
dengan anak & umum. \\
Hanya materi & yang \\
diberikan lebih & sederhana \\
dan simple & \\
\end{tabular} \\
\hline
\end{tabular}

Tabel 2. Instrumen wawancara dengan guru kelas

\begin{tabular}{cl}
\hline No & \multicolumn{1}{c}{ Pedoman Wawancara } \\
\hline 1 & Bagaimana model pembelajaran dalam pendidikan inklusi di sekolah ? \\
2 & Apa strategi dan metode pembelajaran yang digunakan dalam sekolah inklusi ? \\
3 & Bagaimana model evaluasi yang dilakukan dalam sekolah inklusi ? \\
4 & Apa saja sarana dan prasarana yang dibutuhkan dalam menunjang pendidikan inklusi di sekolah ? \\
5 & Apa saja yang menjadi factor penghambat dalam pelaksanaan pembelajaran di sekolah ? \\
6 & Apa saja kesulitan yang dihadapi guru ketika mengajar ABK di sekolah inklusi ? \\
7 & Bagaiman mengatasi kesulitan-kesulitan tersebut ? \\
8 & Apa kelebihan dan kekurangan adanya pendidikan inklusi di sekolah? \\
\hline
\end{tabular}

\section{Tabel 3. Instrumen wawancara dengan guru pendamping}

\begin{tabular}{cl}
\hline No & \multicolumn{1}{c}{ Pedoman wawancara } \\
\hline 1 & Apa peran guru pendamping dalam proses pembelajaran ABK di dalam kelas ? \\
2 & Apa saja tugas dan fungsi guru pendamping dalam proses pembelajaran ABK di dalam kelas ? \\
3 & Bagaimana proses pendampingan guru dalam pembelajaran ABK di kelas ? \\
4 & Bagaimana tahapan-tahapan pendampingan guru selama proses pembelajaran ? \\
5 & Teknis apa digunakan dalam pendampingan dalam proses pembelajaran ABK di kelas? \\
6 & Apa yang menjadi faktor penghambat dan faktor pendukung pendampingan dalam proses \\
& pembelajaran di kelas ? \\
7 & Apa saja kesulitan yang dihadapi dalam mendampingi proses pembelajaran ABK di kelas ? \\
8 & Bagaimana mengatasi kesulitan tersebut? \\
9 & Adakah kegiatan lain untuk ABK yang menunjang dan membantu mereka dalam proses \\
& pembelajaran?
\end{tabular}




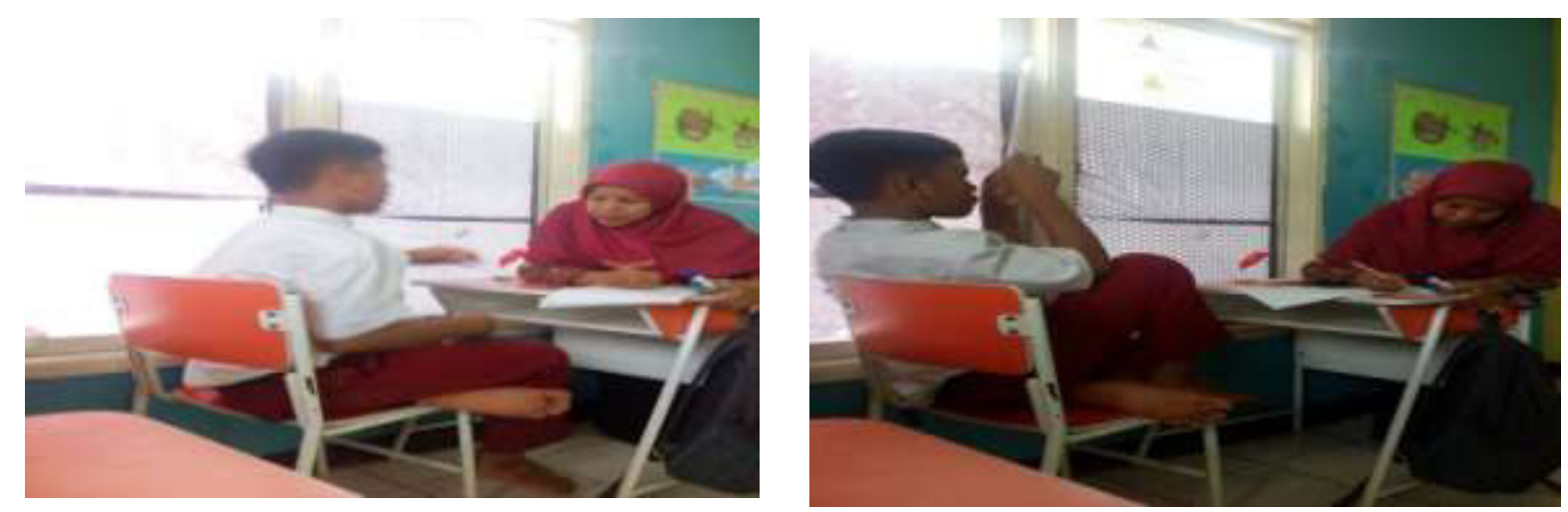

Gambar 1: Foto proses pembelajaran

\section{SIMPULAN}

Berdasarkan hasil penelitian yang telah dilakukan maka dapat disimpulkan beberapa hal sebagai berikut 1) Terdapat perbedaan karakteristik anak berkebutuhan khusus dalam kelas inklusi. Untuk anakanak dengan tipe autis baik sedang maupun ringan membutuhkan kesiapan yang cukup, baik bagi siswa maupun gurunya. Penanganan yang intensif dan terus menerus membuat ABK lebih mandiri dan siap dalam belajar bersama dengan anak umum lainnya. Kurikulum adaptasi sangat dibutuhkan mengingat anak autis mempunyai tingkat intelegensi yang seringkali tidak berbeda jauh dengan anak umum, namun dibutuhkan kesabaran dan kesinambungan dalam pemberian materi. Sedangkan untuk anak dengan tipe slow learner dibutuhkan teknik yang mudah agar mereka lebih mudah dalam memahami materi. Motivasi yang tinggi serta tingkat kreatifitas sangat dibutuhkan untuk menyingkapi kelemahan siswa tipe ini. 2) Terdapat faktor -faktor yang membuat kesulitan belajar matematika anak berkebutahan khusus di kelas inklusi. Seperti misalnya pada anak autis rendah dan sedang, mereka membutuhkan pengulangan pemahaman materi secara terus menerus. Karena kompleknya kemampuan anak autis, dibutuhkan kerjasama yang baik antara orangtua dan pihak sekolah. 3) Terdapat usulan solusi untuk mengatasi kesulitan belajar matematika pada anak berkebutuhan khusus di kelas inklusi dengan cara membuat bahan ajar yang sesuai dengan ABK sesuai dengan tipe dan kesulitankesulitannya. Penetuan kurikulum khusus juga sangat dibutuhkan untuk menentukan pemahaman ABK. Pendampingan secara terus menerus baik untuk perkembangan pribadi maupun pemahaman materi disekolah.

Berdasarkan hasil penelitian yang telah dilakukan maka dapat disarankan beberapa hal sebagai berikut 1) Guru hendaknya berinovasi dalam proses pembelajaran serta lebih mengenal karakteristik setiap individu anak berkebutuhan khusus. Selain itu juga diharapkan mempunyai bahan ajar yang sesuai dengan karakteristik ABK, 2) Sekolah hendaknya bisa mengadakaan test kemampuan potensi akademik yang dimiliki oleh siswanya agar tergambar kemampuan awal yang dimiliki oleh siswa tersebut. Sehingga penanganan lebih lanjut bisa dilaksanakan lebih baik dan tepat sasaran.

\section{DAFTAR PUSTAKA}

[1] Soejadi, Kiat Pendidikan Matematika di Indonesia. Jakarta: Dirjen Dikti Depdikbud, 2011.

[2] Tarmansyah, Inklusi (Pendidikan Untuk Semua). Jakarta: DEPDIKNAS, 2009.

[3] S. Alfani'ma, "Definisi Anak Berkebutuhan Khusus," 201 